published work shows, he has been able to combine successfully. He has been concerned with the mechanism of the antibody response, and in collaboration with Prof. Wilson Smith he has studied the kinetics of the formation of different types of antibody in response to infection with poliomyelitis and influenza viruses. Recently, he has investigated the immunological response in Hashimoto's disease in collaboration with Dr. W. R. Trotter, and has identified the antigen responsible for the positive complement fixation test in this disease. A major interest for some years has been the study of the antigenic characters of influenza viruses and factors in normal sera which combine with these viruses.

\section{Atomic Energy Research Establishment: Solid State Physics Division}

A Solin State Physics Division has been formed at the Atomic Energy Research Establishment, Harwell. Its initial term of reference will be: to carry out basic research leading to greater knowledge and understanding of the structure and behaviour of solids. Dr. W. M. Lomer, at present head of the Theoretical Physics Division, has been appointed head of the new Division. Dr. W. C. Marshall, at present a group leader in the Theoretical Physics Division, is to succeed Dr. Lomer as head of the Division.

The formation of the new Solid State Physies Division reflects the importance which the Authority attaches to a better understanding of the structure and properties of solids. The nuclear reactors at Harwell, and particularly the research reactor Bepo, and the materials testing reactors Dido, Pluto, play a very important part in studies of the properties of materials. The programmes of work fall broadly into two parts. First, there are basic and applied studies of the effects of nuclear radiation on materials of decisive importance to reactor technology : this work will remain under the control of existing Harwell Divisions, particularly the Metallurgy Division. Secondly, there are more basic studies of the behaviour of solids in general, without reference to any particular application in reactor technology : this work will be the special concern of the new Division. It will include studies of the formation and nature of defects in crystals; other physical properties of metals, alloys and magnetic materials; and fundamental crystal physies using extracted beams of neutrons from the Harwell reactors.

\section{The International Atomic Energy Agency}

IN a statement issued in Vienna on the third anniversary of the establishment of the International Atomic Energy Agency, Mr. Sterling Cole, its directorgeneral, said that the experience of three years had demonstrated that a balanced development of the peaceful uses of nuclear energy could be achieved only by international co-operation on the widest possible basis. It was now apparent that the development of reactors, and in particular power reactors, would take considerably longer than was originally expected, but progress in the use of radioisotopes and other radiation sources had been rapid and substantial, especially in industry and medicine. Early hopes that nuclear power would soon become an effective instrument for the rapid industrialization of under-developed countries had been somewhat hampered, and in assisting such States the Agency at this stage was more concerned with preparing the groundwork than with advanced projects. Technical assistance and training were now two of its most important programmes; the exchange and dissemination of information was another developing function; and its research problem was mainly concerned with problems of radiation protection.

\section{The Russian Earth Satellite 1960入}

REFERENCE was made in Nature of September 3, p. 830 , to the Earth satellite $(1960 \lambda)$ or Sputnik 5, on the basis of reports then available. This satellite was launched on August 19 at about 0845 hr. U.T., and consisted of the 'space capsule' itself, and the last stage of the launching rocket. The two objects were seen from the United Kingdom at about 2113 hr. U.T. on August 19 with apparent magnitudes of +3 and +6 , the fainter object following the brighter in the same orbit, with a separation of about $\frac{1}{2}$ whether the brighter or the fainter object was the 'capsule' is not certain. Transmissions from the satellite on frequencies of $19.995,39.990$ and 59.985 Mc./s. were received by staff of the Radio Research Station, Slough, during transits occurring at about $1322 \mathrm{hr} ., 1510 \mathrm{hr} ., 1938 \mathrm{hr}$. and $2113 \mathrm{hr}$. U.T. on August 19. Signals from the satellite were also received at the Radio Research Substation, Singapore, at about $0800 \mathrm{hr}$. U.T. on August 20, but were not received at Slough later that day when the satellite was next due to be in the neighbourhood of Great Britain. This was explained by a Tass report of August 21, in which it was reported that the space capsule was brought out of orbit from a height of about $300 \mathrm{~km}$. soon after $1200 \mathrm{hr}$. U.T. on August 20, having performed 18 revolutions.

Effects of Autonomy on Science and Technology

UNDER the smmewhat misleading title "Local Self-Government", Political and Economic Planning has issued an admirable objective analysis of the experience of such regions of the United Kingdom as Wales, Scotland and Northern Ireland, and also the Isle of Man and of the Channel Islands (Vol. 26, No. 444 (12th September, 1960). Pp. 229-280. (London: Political and Economic Planning, 1960.) $5 s$.). That such an impartial account of the varying degrees of independence and interdependence of the governments of these territories and assessment of the present position scarcely touches on scientific matters as such in itself points to the spurious character of some of the claims for separate national scientific institutions or departments, and although the conclusions drawn touch only on the political and administrative aspects of autonomy, the broadsheet provides a reasoned and impartial appraisal of the arguments for and against autonomy, and of the difficulties and advantages that may well be of service to the scientist or technologist confronted with such claims. It is a real contribution both to the understanding of the present situation and to clear thinking about the real issues involved. The arrangements described are complicated, but it is clear that they are understood by interested and informed opinion in the territories concerned and that while the measure of autonomy enjoyed is varied, it is what it purports to be.

\section{Survey of Information/Library Units in Industrial and Commercial Organizations}

THE results of a survey of the information/library units of some 52 British industrial and commercial 